\title{
卵巣成熟囊胞性奇形腫における腫瘍マーカーとの相関についての検討
}

\author{
君津中央病院 産婦人科
}

平敷好一郎、糸井瑞恵、河原井麗正、木村博昭

\section{Correlation between tumor marker expression and tumor diameter in mature cystic teratoma of the ovary}

\author{
Koichiro Hirashiki, Mizue Itoi, Yoshimasa Kawarai, Hiroaki Kimura \\ Department of Obstetrics and Gynecology, Kimitsu Central Hospital
}

\begin{abstract}
Objective: We investigated the correlation between tumor diameter and the expression of tumor markers in ovarian mature cystic teratoma (MCT).

Methods: Thirty-two patients with MCT who were surgically treated at our hospital between January 2013 and March 2015 were included in this study. We investigated the correlation between tumor diameter and tumor marker expression (squamous cell carcinoma antigen [SCC], carcinoembryonic antigen [CEA], carbohydrate antigen [CA]125, and CA19-9).

Results: The median tumor diameter was $7.8 \mathrm{~cm}$ (range 5.0-16.0 cm). The median values of SCC, CEA, CA125, and CA19-9 were $1.25 \mathrm{ng} / \mathrm{mL}$ (range 0.6-3.5 ng/mL), $1.4 \mathrm{ng} / \mathrm{mL}$ (range 0.5-10.9 ng/mL), $16 \mathrm{U} / \mathrm{mL}$ (range 5.0-86.1 U/mL), and $34.6 \mathrm{U} / \mathrm{mL}$ (range 2.0-949.4 U/mL), respectively. The levels of SCC and CEA showed significant positive correlations with tumor diameter (respective correlation coefficients $=0.499$ and 0.460 ), while the levels of CA19-9 and CA125 showed no significant correlation with the tumor diameter. We also encountered an example of malignant transformation of MCT during the study period. The tumor diameter in this case was $18.8 \mathrm{~cm}$, and the preoperative level of SCC was $25 \mathrm{ng} / \mathrm{mL}$, which is remarkably high, even considering the tumor diameter.

Conclusion: In this study, the levels of SCC and CEA showed significant positive correlations with tumor diameter. High preoperative SCC and CEA levels may suggest that the tumor diameter should be considered when planning laparoscopic surgery. On the other hand, in cases in which the tumor markers are remarkably high, preoperative evaluation for the possibility of malignancy may be necessary.
\end{abstract}

Key words: mature cystic teratoma, tumor marker, tumor diameter

\section{【緒 言】}

成熟囊胞性奇形腫 (Mature cystic teratoma : 以下MCT）は全卵巣腫瘍の10～20\%を占め、生 殖年齢を中心に幅広い年代に認められる代表的な 卵巣腫瘍である ${ }^{1,2)}$ 。その中で $1-2 \%$ と極めて稀 ではあるが、悪性転化を来す症例の存在が知られ て抢り、約 $80 \%$ は扁平上皮癌とされる ${ }^{3)}$ 。近年、 MCTに対する手術療法として腹腔鏡下手術が多 く行われているが、一方で悪性転化の可能性から 術式選択にあたり、術前の鑑別診断は重要である
と考えられる。鑑別としては年齢、腫痬マーカー、

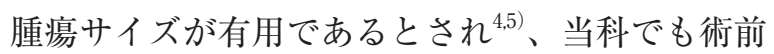
に腫瘍マーカーの測定および超音波、CT、MRI による画像診断等を行っているが、腫瘍マーカー が基準值を超える場合に、どの程度を異常として 考慮すべきか判断に迷う症例も決して少なくな い。今回我々は、自施設で術後にMCTと診断さ れた症例における術前の腫瘍マーカー值と画像上 の腫瘍径との相関の有無について後方視的に検討 を行った。 


\section{【対象と方法】}

2013年 1 月より2015年 3 月までに当科にて手術 を施行し、病理診断にて卵巣のMCTと診断され た32例を対象とし、当院倫理委員会の承認（第 360号）のもと、術前に計測された腫瘍マーカー 值 (血清squamous cell carcinoma antigen (SCC)、 carbohydrate antigen (CA) 125、 carbohydrate antigen (CA) 19-9、 carcino-embryogenic antigen (CEA)) と腫瘍最大径との間の相関関係 につき検討を行った。

腫瘍最大径に関しては、術前に撮影した骨盤 MRIのT2強調画像にて矢状断、横断像より計測 を行った。緊急搬送例などMRI撮影が施行されな かった症例が 32 例中 5 例あり、これらの症例に関 しては術前に行った超音波抢よびCT画像より同 様に最大径の計測を行った。また、両側性の症例 を 2 例認め、両側の内で大きい方を腫瘍最大径と して扱った。腫瘍最大径と各々の腫瘍マーカー值 との間で相関係数（Peason's $r$ ) を求め、その相 関関係の有無につき検討した。

\section{【結 果】}

32例に施行した手術の内訳は、開腹手術 5 例 (付 属器切除 4 例、腫瘍核出術 1 例)、腹腔鏡下手術 27例（付属器切除 9 例、腫瘍核出術18例）であっ た。開腹手術が選択されたのは、卵巣茥捻転での 緊急手術となった症例が 3 例、術前の画像所見で 悪性の可能性が疑われた症例が 1 例、肥満による 症例が 1 例であった。
32例の年齢、BMI、最大腫瘍径、腫瘍マーカー 測定值を表 1 に示す。年齢の中央值は34歳 (範囲: 17 -84歳)、BMIの中央值は21.6 (範囲 : $17.2-$ 30.3 ) であり、最大腫瘍径の中央值は $7.8 \mathrm{~cm}$ (範囲： $5.0-16.0 \mathrm{~cm}$ ）であった。術前の腫瘍マーカー測 定值は、それぞれ中央值でSCC $1.25 \mathrm{ng} / \mathrm{ml}$ (範囲: $0.6-3.5 \mathrm{ng} / \mathrm{ml}$ ）、CA125 $16 \mathrm{U} / \mathrm{ml}$ （範囲 : 5.0 $86.1 \mathrm{U} / \mathrm{ml}$ )、CA19-9 $34.6 \mathrm{U} / \mathrm{ml}$ (範囲: $2.0-$ $949.4 \mathrm{U} / \mathrm{ml}$ )、CEA $1.4 \mathrm{ng} / \mathrm{ml}$ （範囲 : $0.5-10.9$ $\mathrm{ng} / \mathrm{ml}$ ) であり、基準值を超えた割合は、SCC $15.4 \%$ 、CA125 $13.3 \%$ 、CA19 - $943.3 \%$ 、CEA $13.0 \%$ であり、CA19-9で他の腫瘍マーカーに比 べ、基準值を超える症例が多い傾向にあった。

腫瘍マーカー值と腫瘍最大径との間の相関関係 についての検討を図 1 に示す。SCCでは相関係数 $(\mathrm{r})=0.499 、 \mathrm{CEA}$ では $\mathrm{r}=0.460$ と正の相関関係を 認め、いずれも腫瘍径が大きくなるにつれて腫痬 マーカー值が大きくなるという有意な正の相関関 係を認めた（SCC : p = 0.009、CEA : p = 0.027）。 CA125においても $r=0.353$ と正の相関を認めた が、腫瘍径との間の相関関係に有意差は認めなか った（ $\mathrm{p}=0.060) 。 \mathrm{CA} 19-9 て ゙ は \mathrm{r}=-0.007$ とご くわずかな負の相関を認めたが、CA125同様腫痬 径との間の相関関係に有意差は認めなかった（ $\mathrm{p}$ $=0.970) 。 \mathrm{CA} 19-9$ の検討において腫瘍径に比し、 マーカー值が著しく高值（949.4 U/ml） を示す症 例を 1 例認め、その 1 例を除外しての検討も行っ たが、やはりCA19-9と腫瘍径との間に有意な相 関関係は認めなかった。また、両側性の症例が 2 例あり、両方の最大径の和を腫瘍最大径として扱

表 1 患者背景 (年齢、BMI、最大腫瘍径、腫瘍マーカー値)

\begin{tabular}{cc}
\hline $\begin{array}{c}\text { 年齢 (歳) } \\
\text { (中央值、範囲) }\end{array}$ & $34(17-84)$ \\
\hline $\begin{array}{c}\text { BMI } \\
\text { (中央值、範囲) }\end{array}$ & $21.6(17.2-30.3)$ \\
\hline $\begin{array}{c}\text { 最大腫瘍径 }(\mathrm{cm}) \\
\text { (中央值、範囲) }\end{array}$ & $7.8(5.0-16.0)$ \\
\hline \\
\hline
\end{tabular}



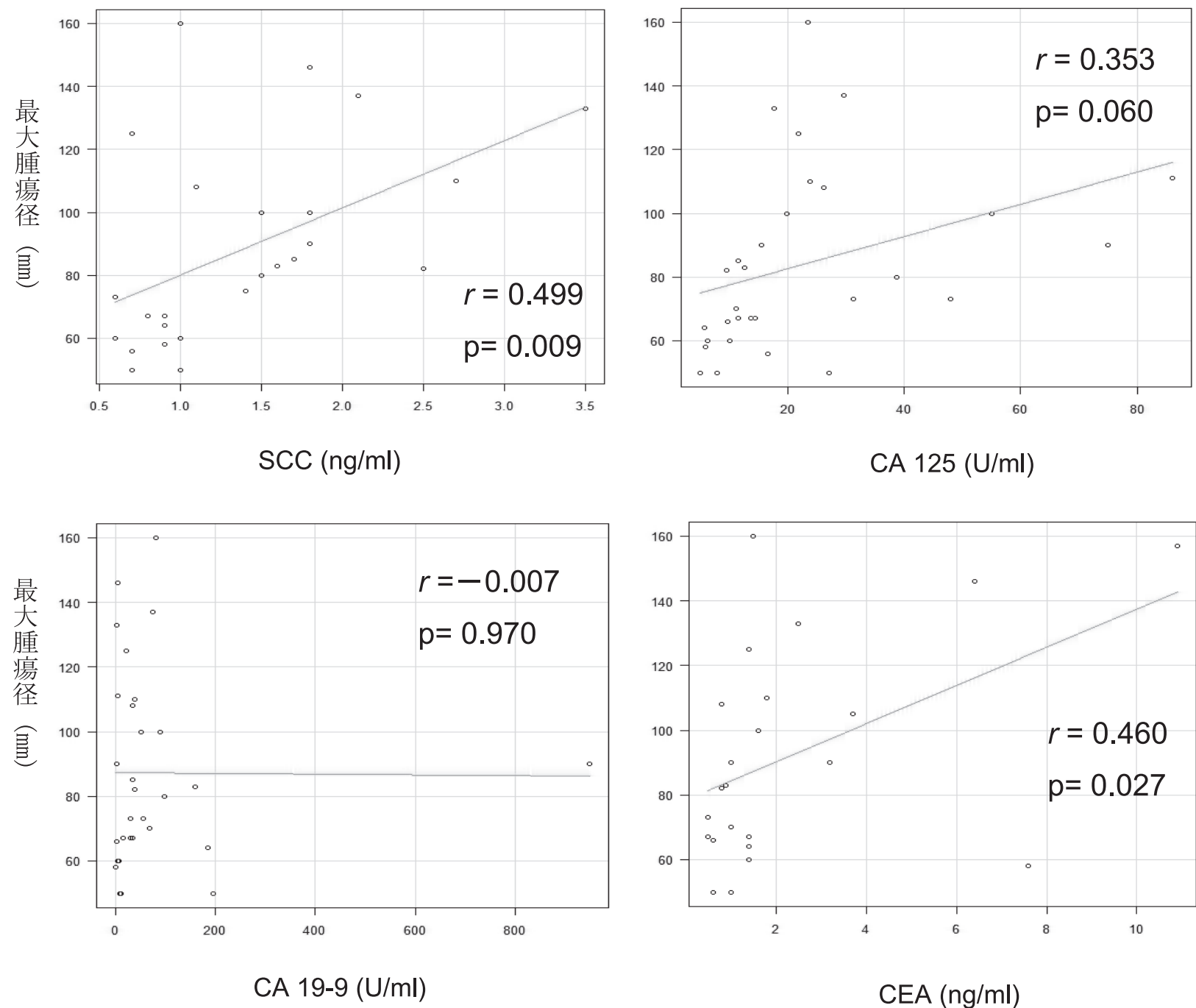

図 1 最大腫瘍径と腫瘍マーカー值の相関関係

最大腫瘍径とSCCおよびCEAとの間に有意な正の相関関係を認める $r$ : Pearson's $r$ 相関係数

い腫瘍マーカーとの間の相関関係についての検討 も行ったが、SCCとCEAにおいて有意な正の相 関関係を認めるという同様の結果であった（SCC： $r=0.538, p=0.001 、$ CEA $: r=0.524, p=0.010) 。$

対象期間中に 1 例、MCTの悪性転化例を認め た。患者年齢は74歳、術前の腫瘍マーカー值は SCC $25.0 \mathrm{ng} / \mathrm{ml} 、$ CA125 $56.2 \mathrm{U} / \mathrm{ml} 、$ CA19-9 $118.3 \mathrm{U} / \mathrm{ml}$ 、CEA $5.9 \mathrm{ng} / \mathrm{ml}$ あ゙り、腫瘍最大径 は18.8cmであった。MRI画像にて腫瘍内に壁在結 節を認めた（図 $2 \mathrm{a} ）$ 。上記検査所見より悪性転化 の可能性を考元手術療法施行。術中の迅速組織診 にて悪性所見認めたため、子宮付属器悪性腫瘍手 術 (子宮全摘 + 両側付属器切除 + 大網切除 + 後腹 膜リンパ節郭清）を施行した。術後の病理診断で は正常の成熟囊胞性奇形腫の所見の一部に扁平上 皮癌を認め、MCTの悪性転化として矛盾しない

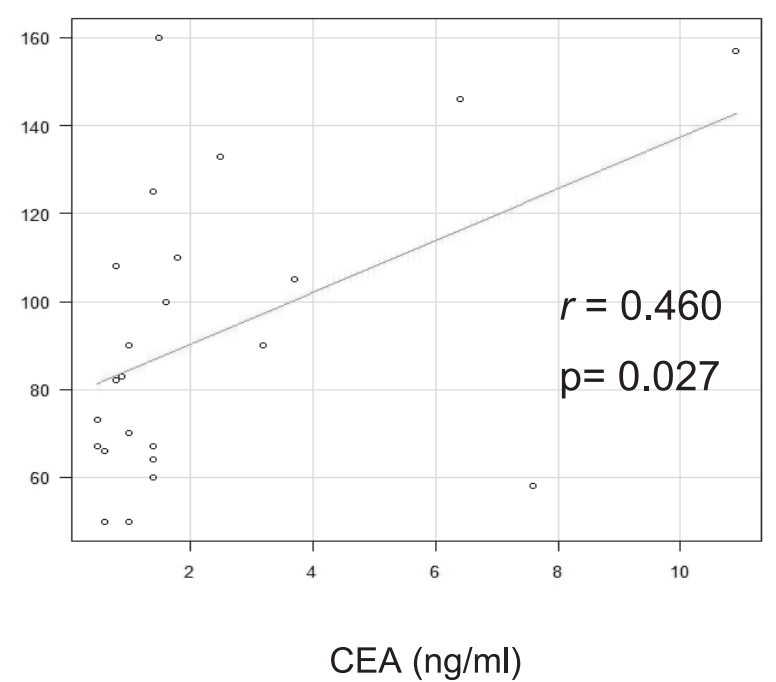

結果であり、stage IA（pTlaN0M0）であった。 $\mathrm{MCT}$ 例での検討にて腫瘍径との間に相関関係を 認めたSCCとCEAについてMCT例と悪性転化例 で比較してみると、特にSCCに関しては腫瘍最大 径を考慮しても悪性転化例では著しい高值を示し ていた（図 $2 b$ )。

\section{【考察】}

MCTは生殖年齢を中心に認められる最も代表 的な良性卵巣腫瘍である ${ }^{1,2)}$ 。産婦人科内視鏡手術 ガイドライン (2013) では、開腹手術に比し術後 疼痛の減弱や合併症の減少、入院期間の短縮が指 摘されている点などを挙げ、良性卵巣腫瘍に対し て腹腔鏡手術は推奨できるとしており 腹腔鏡下手術の最も良い適応の一つと考えられる が、一方で $1-2 \%$ と極めて稀ではあるが、悪性 


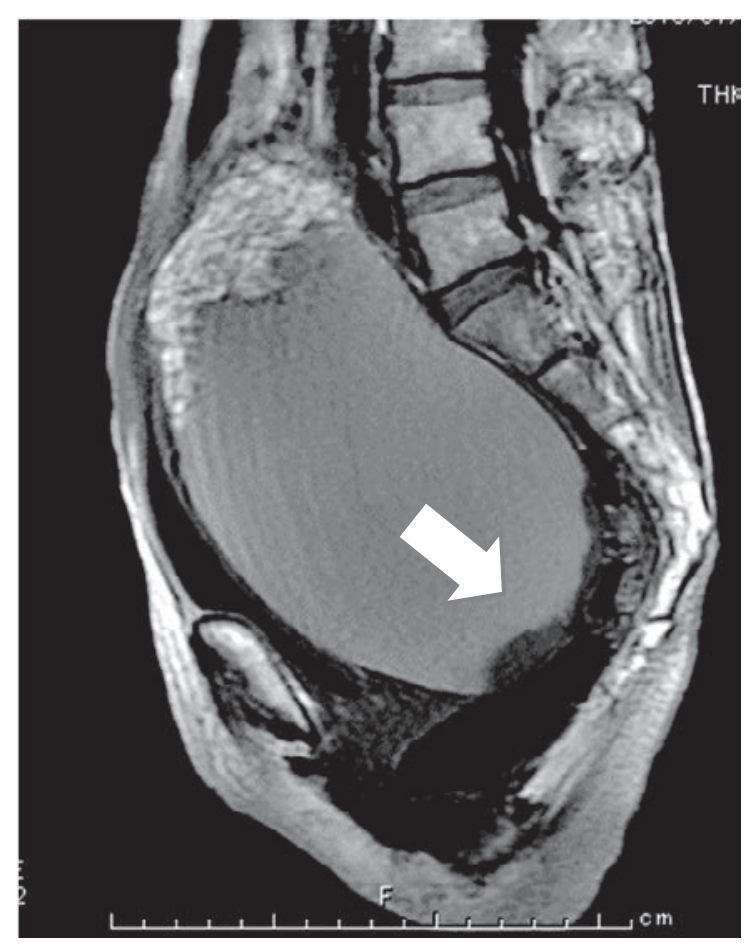

a

図2ＭCT悪性転化例のMRI画像および最大腫瘍径と腫瘍マーカー值 $\mathrm{a}:$ MRI T2強調画像 腫晅内腔に壁在結節を認める $(\Rightarrow)$ 。

$\mathrm{b}$ ：最大腫瘍径と腫瘍マーカー值 MCT例との比較。特にSCCでは腫瘍径を考慮しても著しい高值を示している $(O)$ 。
転化を来す症例の存在が知られていることか $ら^{3)}$ 、術前の診断には患者年齢、画像所見、腫瘍 マーカーの測定などによる慎重かつ総合的な判断 が求められる。

MCTに扔ける腫瘍マーカーの測定では、今回 の検討において基準值を超えた割合は、SCC 15.4 \%、CA125 13.3\%、CA19-9 43.3\%、CEA 13.0 \%であり、これまでの報告と概ね同様の結果であ った ${ }^{7-9)}$ 。SCCに関しては悪性転化との関連が多く 報告されており、Chenら ${ }^{10)}$ は、術前SCCが基準 值を超えていた割合は $81.3 \%$ と高率であったと報 告しており、Futagamiら ${ }^{11)}$ はSCCの中央值に関 してMCTが $0.92 \mathrm{ng} / \mathrm{ml}$ あっったのに対し、悪性 転化では $31.5 \mathrm{ng} / \mathrm{ml}$ と高值であったことを報告し ている。Moriら ${ }^{5)}$ はMCT 81例に悪性転化39例を 加えた検討で、悪性転化の鑑別に最適なSCCの cut-off值を $2.5 \mathrm{ng} / \mathrm{ml}$ （感度 $80 \%$ 、特異度 $94 \%$ ）と しており、さらに年齢が40歳未満でSCCが 2.5 $\mathrm{ng} / \mathrm{ml}$ 超える悪性転化例を認めなかったことか ら両者を併用すことがMCTの悪性転化との鑑別 に有用であり、より安全に腹腔鏡下手術を計画で きるとしている。今回の検討において、SCCが
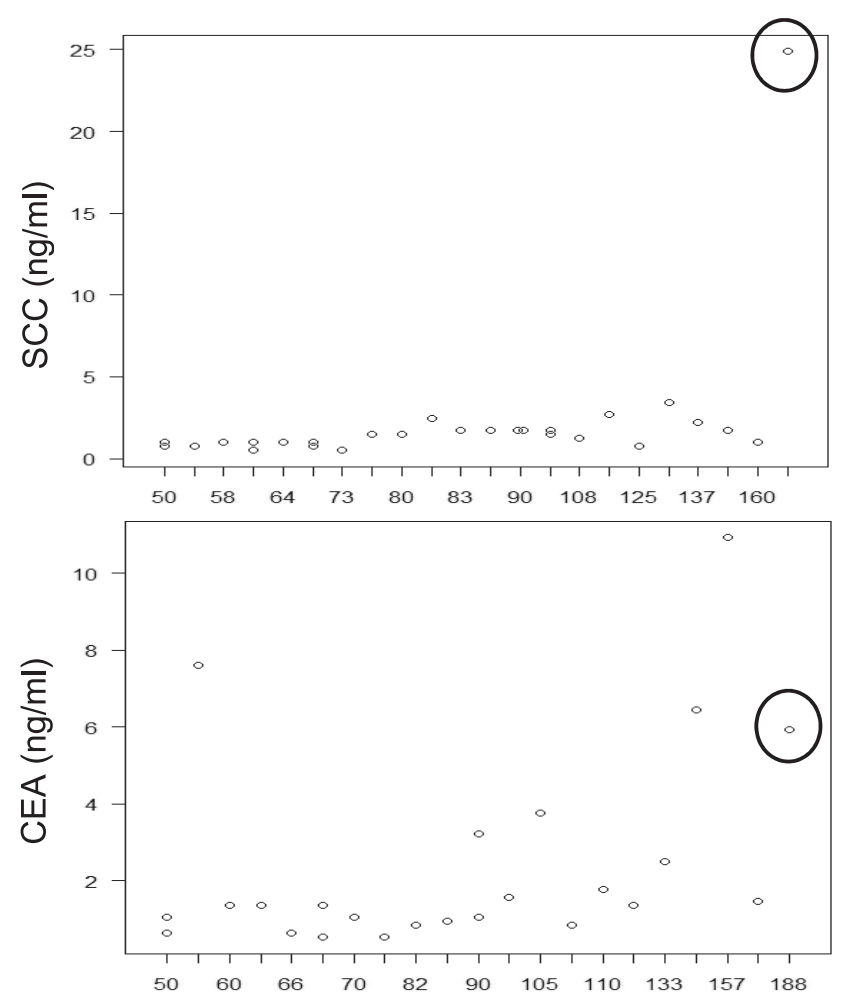

$\mathrm{b}$
最大腫瘍径 $(\mathrm{mm})$
$2.5 \mathrm{ng} / \mathrm{ml}$ 超えた例は 32 例中 2 例 $(2.7 \mathrm{ng} / \mathrm{ml}$ 、 $3.5 \mathrm{ng} / \mathrm{ml}$ ) あったが、年齢はそれぞれ 33 歳、 26 歳といずれも40歳未満であり、上述の報告と同様 の結果であった。他の腫瘍マーカーでは、CEA に関しては、Kikkawaら ${ }^{4)}$ は年齢45歳以上で腫瘍 径 $99 \mathrm{~mm}$ 以上の場合にはSCCとともにCEAを測定 することが有用であると述べており、悪性転化例 で有意に高值であったとする報告も認められ る ${ }^{12)}$ 。CA125に関してはMCTでもしばしば異常 值をとるとする報告 ${ }^{8)} 、 \mathrm{CEA}$ 同様SCCとともに悪 性転化の鑑別に有用であるとする報告が認められ る ${ }^{13)}$ 。今回の研究でCA19-9において他の腫瘍マ 一カーと比較し基準值を超える症例の割合が高い 傾向にあった。諸家の報告でもMCTにおいて CA19-9の陽性率が高いことは示されていてお

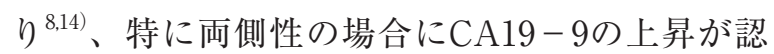
められることから両側性の MCTを予測する因子 となり得ることを指摘している報告もあるが7.8)、 本研究では32例中 2 例が両側性で、CA19-9の值 はいずれも中央值をわずかに超える程度で明らか に高值を示すことはなかった。CA19-9に関して Itoは ${ }^{15)}$ 、免疫組織化学的検討にてMCT内の気管 
支腺組織および気管支上皮にCA19-9の局在を認 めたことから、MCTの腫瘍組織自体からのCA19 -9産生を指摘している。また、CA19-9はLewis 式血液型Lewis $\mathrm{A}\left(\mathrm{Le}^{\mathrm{a}}\right)$ の糖鎖をシアル化した 抗原であるとされ、日本人では $5-10 \%$ 程度で遺 伝的に陰性者が存在し、このような症例では CA19-9が陰性となることが知られている。この 点についても同様に考察がなされており、本邦で はCA19-9がMCTにおいては必ずしも悪性転化 の判定に有用でない可能性があるのではないかと 考えられた。

MCTにおいて、腫瘍径に関しては、平均で 7 $-8 \mathrm{~cm}$ 程度とする報告が多いが7,11,14)、その中に は $10 \mathrm{~cm}$ 超えるような症例も多く含まれ、前述 のようにMCTでは一定の割合で腫瘍マーカーが 基準值を超えることから、悪性転化の除外を含め 術前診断に迷うような症例が少なからず存在する と思われる。MCTにおける腫瘍径と腫瘍マーカ 一の関係では、Kataokaら ${ }^{8)}$ はCA125とCA19-9 において腫瘍径との間に有意な正の相関を認めた が、SCCでは有意な相関は認めなかったと報告し ている。また、一方で山下ら ${ }^{9)}$ の報告では、腫瘍 表面積との検討でSCCとの間に正の相関関係が認 められたとしている。CEAに関しては、MCTと の関係について検討しているDedeら ${ }^{7)}$ の報告で 明らかな相関関係は示されなかった。今回の検討 ではMCTにおいて腫瘍最大径とSCCおよびCEA の間に相関関係を認めた。これまでの報告とは必 ずしも一致しない結果であるが、MCTにおいて 腫瘍マーカーが基準值を超える場合でも腫瘍径 （最大径）を考慮し、腫瘍径が大きい場合は腫瘍 マーカーが異常值を取り得ることを念頭に入れな がら、術前診断および術式選択を行う必要がある ことを示唆する結果ではないかと考えられた。

期間中、 1 例MCTの悪性転化症例を経験した。 患者年齢は74歳、腫瘍最大径は $18.8 \mathrm{~cm}$ であり、い ずれも今回の検討における MCT症例の中央值を 大きく上回っており、MCT悪性転化例において 平均もしくは中央值で年齢は $40-50$ 歳代、腫瘍径 は $10 \mathrm{~cm}$ 程度からそれ以上とするこれまでの諸家

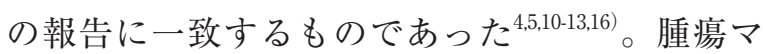
ーカーでは、SCCが $25 \mathrm{ng} / \mathrm{ml}$ と特に高值を示し ており、これらは前述したMoriら ${ }^{5)}$ が報告の中で、 悪性転化のcut-off值として示している $2.5 \mathrm{ng} / \mathrm{ml}$ を大きく上回るものであった。また、悪性転化を 示唆する画像所見としては囊胞内部の充実部の存 在が挙げられる。他の上皮性卵巣悪性腫瘍と同様
に造影効果を伴う乳頭状〜カリフラワー状の充実 部の存在は悪性転化を疑う所見であるが、一方で MCTにおいてはRokitansky隆起もしくはdermoid nippleと呼ばれ様々な良性組織を含み内容によっ ては強い造影効果を認めることもある壁在結節を 認めることがあり、注意が必要である ${ }^{17)}$ 。悪性転 化を疑う壁在結節の特徵として、結節と囊胞壁が 鋭角を成す ${ }^{18)}$ 、充実部が囊胞壁外や近接臟器への 直接浸潤を示す ${ }^{17)}$ 、などといった点が指摘されて いる。今回我々が経験した悪性転化例ではMRIに て襄胞壁内部に壁在結節を認めたが、全体に平滑 で囊胞壁となす角度も鈍的なやや扁平なもので、 明らかな壁外浸潤は認めず、上述のような特徵は 認めなかった。しかしながら、年齢、腫瘍径、腫 瘍マーカー值を併せた総合的な判断として悪性転 化を念頭に治療計画を立てるべき症例であったと 考えられる。

\section{【結語】}

今回の検討で、術前の腫瘍マーカーでSCCおよ びCEAにおいて腫瘍最大径との間に有意な正の 相関関係を認めた。MCTにおいて術前に悪性転 化の可能性を除外し安全に腹腔鏡下手術を計画す るにあたり、腫瘍マーカー值が異常值を示す場合 でも腫瘍径が大きい場合には、その大きさが原因 である可能性もあり得ることから、腫瘍最大径は 考慮すべき因子となる可能性が示唆された。一方 で腫瘍マーカー值が著しい高值を示す例では、年 齢や画像所見も含め悪性の可能性も十分に念頭に 入れた術前の評価が必要であると考えられた。

本論文の要旨は第 55 回日本産科婦人科内視鏡学 会に抒いて発表した。

すべての著者は開示すべき利益相反はない。

\section{参考文献}

1) Peterson WF, et al. : Benign cystic teratomas of the ovary ; a clinico-statistical study of 1,007 cases with a review of literature. Am J Obstet Gynecol 1955 ; $70: 368-82$

2) Roth LM, Talerman A. : Recent advances in the pathology and classification of ovarian germ cell tumors. Int J Gynecol Pathol 2006 ; 25 : 305-20.

3 ) Peterson WF. : Malignant degeneration of benign cystic teratomas of the ovary ; a collective review of the literature. Obstet Gynecol Surv 1957 ; 12 : 793-830. 
4) Kikkawa F, et al. : Diagnosis of squamous cell carcinoma arising from mature cystic teratoma of the ovary. Cancer $1989 ; 82: 2249-55$.

5 ) Mori Y, et al. : Preoperative diagnosis of malignant transformation arising from mature cystic teratoma of the ovary. Gynecol Oncol $2003 ; 90: 338-41$.

6 ）日本産婦人科内視鏡学会編：産婦人科内視鏡手術ガ イドライン 2013 年版、金原出版.

7 ) Dede M, et al. : CA19-9 may have clinical significance in mature cystic teratoma of the ovary. Int J Gynecol Oncol 2006 ; 16 : 189-93

8 ) Kataoka T, et al. : Retrospective evaluation of tumor markers in ovarian mature cystic teratoma and ovarian endometrioma. J Obstet Gynaecol Res 2012 ; $38: 1071-6$

9 ）山下 博 他：当院における卵巣成熟奇形腫手術症 例の検討. 日産婦内視鏡学会2017;33:74-8

10) Chen RJ, et al. : Prognosis and treatment of squamous cell carcinoma from a mature cystic teratoma of the ovary. J Formos Med Assoc 2008 ; $107: 857-68$

11) Futagami M, et al. : Can malignant transformation in mature cystic teratoma be preoperative predicted ?. Eur J Gynaecol Oncol $2012 ; 33: 662-5$

12）牧原夏子 他：卵巣奇形腫における悪性転化の術前 予測についての検討. 日産婦内視鏡学会 2014；30： $112-6$

13) Hackethal A, et al. : Squamous-cell carcinoma in mature cystic teratoma of the ovary : systemic review and analysis of publish data. Lancet Oncol $2008 ; 9: 1173-80$

14) Ustunyurt E, et al. : Tumor markers in mature cystic teratoma of the ovary. Arch Gynecol Obstet $2009 ; 279: 145-7$

15) Ito K. : CA19-9 in Mature Cystic Teratoma. Tohoku J. Exp. Med. 1994 ; 172 : 133-8

16) Rim S Y. et al. : Malignant transformation of ovarian mature cystic teratoma. Int J Gynecol Cancer 2006 ; $16: 140-144$

17) Kido A. et al. : Dermoid cysts of the ovary with malignant transformation: MR appearance. AJR $1999 ; 172: 445-9$

18) Poncelet E. et al. : Value of dynamic contrastenhanced MRI for tissue characterization of ovarian teratomas: correlation with histopathology. Clin Radiol 2013 ; 68 : 909-16

投稿日：2017年 9 月 20 日

採択日：2017年12月20日 